\title{
Thermoanaerobacter siderophilus sp. nov., a novel dissimilatory Fe(III)-reducing, anaerobic, thermophilic bacterium
}

\author{
A. I. Slobodkin, T. P. Tourova, B. B. Kuznetsov, N. A. Kostrikina, \\ N. A. Chernyh and E. A. Bonch-Osmolovskaya
}

Institute of Microbiology, Russian Academy of Sciences, Prospect 60-letiya Oktyabrya 7/2, 117811 Moscow, Russia
Author for correspondence: Alexander Slobodkin. Tel: +795 135 4458. Fax: +7951356530. e-mail: slobodki@inmi.host.ru

\begin{abstract}
A thermophilic, anaerobic, spore-forming, dissimilatory Fe(III)-reducing bacterium, designated strain SR4 ${ }^{\top}$, was isolated from sediment of newly formed hydrothermal vents in the area of the eruption of Karymsky volcano on the Kamchatka peninsula. Cells of strain SR4' were straight-to-curved, peritrichous rods, 0.4-0.6 $\mu \mathrm{m}$ in diameter and 3.5-9.0 $\mu \mathrm{m}$ in length, and exhibited a slight tumbling motility. Strain SR4 ${ }^{\top}$ formed round, refractile, heatresistant endospores in terminally swollen sporangia. The temperature range for growth was 39-78 ${ }^{\circ} \mathrm{C}$, with an optimum at 69-71 ${ }^{\circ} \mathrm{C}$. The $\mathrm{pH}$ range for growth was 4.8-8.2, with an optimum at 6.3-6.5. Strain SR4 ${ }^{\top}$ grew anaerobically with peptone as carbon source. Amorphous iron(III) oxide present in the medium stimulated the growth of strain $\mathrm{SR4}^{\mathrm{T}}$; cell numbers increased with the concomitant accumulation of Fe(II). In the presence of Fe(III), strain SR4 ${ }^{\top}$ grew on $\mathrm{H}_{2} / \mathrm{CO}_{2}$ and utilized molecular hydrogen. Strain $\mathrm{SR4}^{\top}$ reduced 9, 10anthraquinone-2,6-disulfonic acid, sulfite, thiosulfate, elemental sulfur and $\mathrm{MnO}_{2}$. Strain $\mathrm{SR4}^{\mathrm{T}}$ did not reduce nitrate or sulfate and was not capable of growth with $\mathrm{O}_{2}$. The fermentation products from glucose were ethanol, lactate, $\mathrm{H}_{2}$ and $\mathrm{CO}_{2}$. The $\mathrm{G}+\mathrm{C}$ content of DNA was $32 \mathrm{~mol} \%$. $16 \mathrm{~S}$ rDNA sequence analysis placed the organism in the genus Thermoanaerobacter. On the basis of physiological properties and phylogenetic analysis, it is proposed that strain SR4 $^{\top}$ ( = DSM 12299') should be assigned to a new species, Thermoanaerobacter siderophilus sp. nov.
\end{abstract}

Keywords: Thermoanaerobacter, Fe(III) reduction, Mn(IV) reduction, thermophiles, magnetite

\section{INTRODUCTION}

Reduction of $\mathrm{Fe}(\mathrm{III})$ by micro-organisms has important implications in the cycling of iron and organic matter and has been intensively studied in marine and freshwater anoxic sediments and submerged soils (Lovley, 1991, 1995; Nealson \& Saffarini, 1994). Dissimilatory $\mathrm{Fe}(\mathrm{III})$-reducing micro-organisms have also been found in a variety of thermobiotic environments, including sediments of hydrothermal vents and hot springs (Slobodkin et al., 1995; Slobodkin \& Wiegel, 1997), sedimentary basins in the deep ter-

Abbreviation: AQDS, 9,10-anthraquinone-2,6-disulfonic acid.

The GenBank accession number for the $16 \mathrm{~S}$ rDNA sequence of strain SR4 ${ }^{\top}$ is AF120479. restrial subsurface (Boone et al., 1995; Liu et al., 1997) and submarine petroleum reservoirs (Greene et al., 1997).

Dissimilatory $\mathrm{Fe}(\mathrm{III})$-reducing micro-organisms can be subdivided into several physiological groups according to the electron donor used for Fe(III) reduction: (i) fermentative, which use Fe(III) reduction as a minor pathway for electron flow while fermenting sugars or amino acids; (ii) hydrogen-oxidizing; (iii) sulfur-oxidizing; and (iv) organisms that oxidize poorly fermentable substrates, such as organic acids, alcohols and aromatic compounds.

Iron-reducing thermophiles available in pure culture are represented by several phylogenetically diverse micro-organisms. The aerobic archaeon Sulfolobus 
acidocaldarius reduces $\mathrm{Fe}(\mathrm{III})$ with elemental sulfur (Brock \& Gustafson, 1976). The anaerobic Bacillus infernus reduces $\mathrm{Fe}(\mathrm{III})$ with formate or lactate as the electron donor (Boone et al., 1995). The anaerobic (eu)bacteria Deferribacter thermophilus (Greene et al., 1997) and Thermoterrabacterium ferrireducens (Slobodkin et al., 1997) couple Fe(III) reduction with the oxidation of complex organic substrates, organic acids, alcohols and molecular hydrogen. Recently, the ability to reduce $\mathrm{Fe}(\mathrm{III})$ with glycerol under oxygen limitation was shown for the moderately thermophilic acidophiles Sulfobacillus thermosulfidooxidans, Sulfobacillus acidophilus and Acidimicrobium ferrooxidans (Bridge \& Johnson, 1998).

In this paper, we describe an anaerobic, dissimilatory $\mathrm{Fe}(\mathrm{III})$-reducing, thermophilic bacterium, Thermoanaerobacter siderophilus sp. nov., isolated from hydrothermal vents on the Kamchatka peninsula.

\section{METHODS}

Environmental samples. Samples of sediments and water were collected in March 1997 from newly formed hydrothermal vents in the area of the eruption of Karymsky volcano on the Kamchatka peninsula. The temperatures at the sampling sites ranged from 70 to $94{ }^{\circ} \mathrm{C}, \mathrm{pH}$ from 6.1 to $7 \cdot 1$ and $E_{h}$ from -215 to $-305 \mathrm{mV}$.

Media and cultivation. A basal medium used for enrichment, isolation and cultivation of $\mathrm{Fe}$ (III)-reducing bacteria was prepared anaerobically by boiling and cooling it under $\mathrm{CO}_{2}$ $(100 \%)$ gas phase. The basal medium contained $\left(\mathrm{l}^{-1}\right.$ distilled water): $0.33 \mathrm{~g} \mathrm{KH}_{2} \mathrm{PO}_{4}, 0.33 \mathrm{~g} \mathrm{NH}_{4} \mathrm{Cl}, 0.33 \mathrm{~g} \mathrm{KCl}, 0.33 \mathrm{~g}$ $\mathrm{MgCl}_{2} .2 \mathrm{H}_{2} \mathrm{O}, 0.33 \mathrm{~g} \mathrm{CaCl} .2 \mathrm{H}_{2} \mathrm{O}, 2.0 \mathrm{~g} \mathrm{NaHCO}, 10 \mathrm{~g}$ peptone, 0.20 g yeast extract (Difco), $10 \mathrm{ml}$ vitamin solution (Wolin et al., 1963) and $1 \mathrm{ml}$ trace-element solution (Slobodkin et al., 1997). The $\mathrm{pH}$ was adjusted to 6.5-6.8 (at $25^{\circ} \mathrm{C}$ ) with $10 \%(\mathrm{w} / \mathrm{v}) \mathrm{NaOH}$. No reducing agent was added to the medium. Fe(III) was provided in the form of amorphous iron(III) oxide at about $90 \mathrm{mmol} \mathrm{Fe}(\mathrm{III}) \mathrm{l}^{-1}$ medium. The amorphous iron(III) oxide was synthesized by titrating a solution of $\mathrm{FeCl}_{3}$ with $10 \%(\mathrm{w} / \mathrm{v}) \mathrm{NaOH}$ to $\mathrm{pH}$ $9 \cdot 0$. The $\mathrm{pH}$ of the autoclaved medium measured at $70^{\circ} \mathrm{C}$ was $6 \cdot 8-6 \cdot 9$.

Unless otherwise noted, enrichments and pure cultures were grown in $10 \mathrm{ml}$ medium in Hungate tubes under an atmosphere of $\mathrm{CO}_{2}(100 \%)$. All transfers and sampling of cultures were performed with syringes and needles. The medium was heat-sterilized at $135^{\circ} \mathrm{C}$ for $30 \mathrm{~min}$. All incubations were at $70^{\circ} \mathrm{C}$ unless otherwise noted.

Physiological studies. Growth of bacteria in medium containing amorphous iron(III) oxide or other insoluble compounds was determined by direct counting with a phasecontrast microscope and a counting chamber. In media with soluble components, growth was determined by counting and by measuring the increase in optical density at $600 \mathrm{~nm}$ (Spekol 10; Carl Zeiss Jena).

The ability of the organism to grow on different substrates was determined in basal medium, in which peptone was replaced by autoclaved or filter-sterilized substrates, both in the presence and in the absence of amorphous iron(III) oxide. When $\mathrm{Fe}(\mathrm{III})$ was omitted, the medium was prereduced with $\mathrm{Na}_{2} \mathrm{~S} .9 \mathrm{H}_{2} \mathrm{O}\left(0.5 \mathrm{~g} \mathrm{l}^{-1}\right)$. The potential for molecular hydrogen to serve as an electron donor was studied in $60-\mathrm{ml}$ flasks containing $10 \mathrm{ml}$ medium and $\mathrm{H}_{2}$ $(100 \%)$ or $\mathrm{H}_{2} / \mathrm{CO}_{2}(5: 95 \mathrm{v} / \mathrm{v})$ as the gas phase. The cultures were incubated for 2 weeks and the ability to utilize a particulate substrate was judged from culture growth and $\mathrm{Fe}(\mathrm{II})$ accumulation. A medium in which the organic carbon source had been omitted was used as a control.

The ability to use various electron acceptors was studied in the basal medium containing peptone $\left(10 \mathrm{~g}^{-1}\right)$ as a sole electron donor, in which amorphous iron(III) oxide was omitted. The electron acceptors were added from autoclaved stock solutions. $\mathrm{MnO}_{2}$ was prepared by the method of Lovley \& Phillips (1988). The medium was pre-reduced with $\mathrm{Na}_{2} \mathrm{~S} .9 \mathrm{H}_{2} \mathrm{O}\left(0 \cdot 5 \mathrm{~g} \mathrm{l}^{-1}\right)$ in the experiments with sulfate, sulfite, thiosulfate and elemental sulfur. No reducing agent was present in media containing $\mathrm{O}_{2}, \mathrm{MnO}_{2}$ or 9 , 10-anthraquinone-2,6-disulfonic acid (AQDS). Both reduced and reducing-agent-free media were used in nitrate-amended experiments. Cultures grown in pre-reduced basal medium without any electron acceptor were used as inocula $(5 \%$ $\mathrm{v} / \mathrm{v}$ ). The use of the electron acceptors was judged from culture growth (for all acceptors), sulfide production (for sulfate, sulfite, thiosulfate and elemental sulfur), change of visible colour of the medium or precipitate (for $\mathrm{MnO}_{2}$ and AQDS) and from the accumulation of $\mathrm{Mn}$ (II) (for $\mathrm{MnO}_{2}$ ).

Temperature, $\mathrm{pH}$ and $\mathrm{NaCl}$ concentration ranges for growth and susceptibility to antibiotics were determined in basal medium in which amorphous iron(III) oxide was omitted and peptone was replaced by glucose $\left(5 \mathrm{~g} \mathrm{l}^{-1}\right)$. The medium was pre-reduced with $\mathrm{Na}_{2} \mathrm{~S} .9 \mathrm{H}_{2} \mathrm{O}\left(0.5 \mathrm{~g} \mathrm{l}^{-1}\right)$. The $\mathrm{pH}$ range for growth was determined at $70^{\circ} \mathrm{C}$. The $\mathrm{pH}$ was adjusted with sterile stock solutions of $\mathrm{HCl}$ or $\mathrm{NaOH}$ and measured at $70^{\circ} \mathrm{C}$ with a model PHM $82 \mathrm{pH}$ meter (Radiometer) equipped with a temperature probe and calibrated at $70^{\circ} \mathrm{C}$.

Microscopy. Routine examinations and cell counting were performed under a phase-contrast Amplival microscope (Carl Zeiss Jena). Transmission electron microscopy was performed with a model JEM-100 electron microscope (JEOL) as described previously (Bonch-Osmolovskaya et al., 1990). Gram staining was performed according to Norris \& Swain (1971).

Analytical techniques. Fe(III) reduction was monitored by measuring the accumulation of $\mathrm{Fe}$ (II) over time. Fe(II) was measured by adding a $0.5 \mathrm{ml}$ sample from the culture to $5 \mathrm{ml}$ $0.6 \mathrm{M} \mathrm{HCl}$. After $24 \mathrm{~h}$ extraction, $\mathrm{HCl}$-soluble $\mathrm{Fe}(\mathrm{II})$ was determined with 2,2'-dipyridyl (Balashova \& Zavarzin, 1980). Iron-containing precipitate was analysed by X-ray diffraction analysis (Slobodkin et al., 1995). Mn(II) was analysed by atomic absorption spectrophotometry after $\mathrm{HCl}$ extraction (Lovley \& Phillips, 1988). Determination of short-chain organic acids, alcohols and gaseous products of metabolism was performed by GC; sulfide was determined by a colorimetric method as described previously (Slobodkin \& Bonch-Osmolovskaya, 1994).

Cultivation of reference strains. Thermoanaerobacter sulfurophilus strain L-64 ${ }^{\mathrm{T}}$ (= DSM $11584^{\mathrm{T}}$ ) was from the culture collection of the Laboratory of Hyperthermophilic Microbial Communities, Institute of Microbiology, Russian Academy of Sciences, Moscow, Russia. Thermoanaerobacter wiegelii strain Rt8.B1 ${ }^{\mathrm{T}}$ (= DSM $10319^{\mathrm{T}}$ ) was obtained from the Deutsche Sammlung von Mikroorganismen und Zellkulturen, Braunschweig, Germany. The strains were routinely cultured in the mineral medium described above with glucose $\left(5 \mathrm{~g}^{-1}\right)$ as the main energy source. Tests for 
Fe(III) reduction were performed in the basal medium with amorphous iron(III) oxide as an electron acceptor; the electron donors were $20 \mathrm{mM}$ lactate (for Thermoanaerobacter sulfurophilus), $20 \mathrm{mM}$ glycerol (for Thermoanaerobacter wiegelii) or $1 \% \mathrm{w} / \mathrm{v}$ peptone (for both strains). The cultivation temperature was $60^{\circ} \mathrm{C}$ for Thermoanaerobacter sulfurophilus and $65^{\circ} \mathrm{C}$ for Thermoanaerobacter wiegelii.

DNA characteristics. The DNA was extracted and purified by the method of Marmur (1961). Its base composition was determined from the melting point according to Marmur \& Doty (1962). The molecular mass of genome DNA was determined based on optical renaturation-rate measurements (Gillis et al., 1970). DNA-DNA hybridization studies were performed by the optical reassociation method as described previously (Krivenko et al., 1990).

165 rRNA sequence studies. The $16 \mathrm{~S}$ rRNA gene was selectively amplified from genomic DNA by PCR using 5'AGAGTTTGATCCTGGCTCAG-3' as the forward primer and 5'-TACGGTTACCTTGTTACGACTT-3' as the reverse primer (Lane, 1991).

The PCR was carried out in $100 \mu$ l reaction mixture containing $1 \mu \mathrm{g}$ DNA template, $200 \mu \mathrm{M}$ (each) primers, $200 \mu \mathrm{M}$ (each) dNTPs and $3 \mathrm{U}$ Tet-z polymerase (BioMaster) in reaction buffer $(100 \mathrm{mM}$ Tris $/ \mathrm{HCl} \mathrm{pH} 8.3$, $500 \mathrm{mM} \mathrm{KCl}, 20 \mathrm{mM} \mathrm{MgCl}_{2}$ ). The temperature cycling was done by using 30 amplification cycles of $1 \mathrm{~min}$ at $94^{\circ} \mathrm{C}$, $1 \mathrm{~min}$ at $42^{\circ} \mathrm{C}$ and $1 \mathrm{~min}$ at $72^{\circ} \mathrm{C}$. The final extension was carried out at $72^{\circ} \mathrm{C}$ for $6 \mathrm{~min}$. The PCR products were purified using the PCR-prep kit (Promega) as recommended by the manufacturer. The 16S rRNA gene was sequenced in both directions with the use of forward and reverse primers. DNA sequencing was performed by using Sequenase version 2.0 (USB).

The 16S rDNA sequence was aligned with a representative set of 16S rRNA sequences obtained from the Ribosomal Database Project or from recent GenBank releases by using MULTALIN software (Corpet, 1988). Positions that had not been sequenced in one or more reference organisms were omitted and a total of 1593 nucleotides were used in the analysis. Pairwise evolutionary distances were computed by using the correction of Jukes \& Cantor (1969). The rooted phylogenetic tree was constructed by the neighbour-joining method (Saitou \& Nei, 1987) with bootstrap analysis of 100 trees using the programs of the TREECON package (Van de Peer \& De Wachter, 1994).

Nucleotide sequence accession numbers. The accession numbers of the sequences used as references were as follows: Thermoanaerobacter thermohydrosulfuricus DSM 567 L09161; Thermoanaerobacter sulfurophilus L-64 ${ }^{\mathrm{T}}$, Y16940; Thermoanaerobacter wiegelii Rt8.B1 ${ }^{\mathrm{T}}$, X92513; Thermoanaerobacter acetoethylicus ATCC 33265 $5^{\mathrm{T}}$, L09163; Thermoanaerobacter kivui DSM 2030 ${ }^{\mathrm{T}}$, L09160; Thermoanaerobacter brockii DSM 1457 $7^{\mathrm{T}}$, L09165; Thermoanaerobacter mathranii $\mathrm{A}^{\mathrm{T}}$, Y11279; Thermoanaerobacter thermocopriae JT-3 ${ }^{\mathrm{T}}$, L09167; Thermoanaerobacter ethanolicus JW-200 ${ }^{\mathrm{T}}$, L09162; Desulfotomaculum thermobenzoicum TSB $^{\mathrm{T}}$, L15628; Thermoanaerobacterium thermosulfurigenes E100-69 , L09161; Dictyoglomus thermophilum H-6-12 ${ }^{\mathrm{T}}$, X69194; Anaerobranca horikoshii JW/YL-138 ${ }^{\mathrm{T}}$; Bacillus infernus $\mathrm{TH}-22^{\mathrm{T}}$, U20384; Moorella thermoautotrophica JW $701 / 5^{\mathrm{T}}$, X58354; Deferribacter thermophilus $\mathrm{BMA}^{\mathrm{T}}$, U75602; Syntrophospora bryantii DSM 3014B ${ }^{\mathbf{T}}$, M26491; and Thermoterrabacterium ferrireducens JW/AS-Y $7^{\mathrm{T}}$, U76363.

\section{RESULTS}

\section{Enrichment and isolation}

Four sediment/water samples obtained from newly formed hydrothermal vents in the area of the eruption of Karymsky volcano on the Kamchatka peninsula were used for enrichment of thermophilic, dissimilatory Fe(III)-reducing micro-organisms. Basal anaerobic medium, in which peptone was an electron donor and amorphous iron(III) oxide was provided as an electron acceptor, was inoculated with $10 \%(\mathrm{w} / \mathrm{v})$ of the sample and incubated at $85^{\circ} \mathrm{C}$ in the dark. After 2 weeks incubation, no accumulation of $\mathrm{Fe}$ (II) was observed. After that, the same flasks were incubated at $70^{\circ} \mathrm{C}$. After $72-96 \mathrm{~h}$ cultivation, in two enrichments, non-magnetic, brown amorphous iron(III) oxide was converted to a black, solid material of less volume, which was strongly attracted to a magnet and contained a significant amount of $\mathrm{Fe}(\mathrm{II})$. For the isolation of a pure culture, the enrichment with the fastest rate of $\mathrm{Fe}(\mathrm{III})$ reduction (sampling point: $\mathrm{T}=94{ }^{\circ} \mathrm{C}, \mathrm{pH}$ $=6 \cdot 1, \mathrm{E}_{\mathrm{h}}=-215 \mathrm{mV}$ ) was chosen. After three successive $5 \%(\mathrm{w} / \mathrm{v})$ transfers, the enrichment was repeatedly serially diluted to extinction in the basal medium in which iron(III) oxide was replaced by AQDS (20 mM). The highest dilution that was positive for AQDS reduction $\left(10^{-6}\right)$ was serially diluted to extinction in agar shake tubes $(1.5 \%$ Bacto Agar) in the basal medium with AQDS. Single colonies were removed and subcultured in liquid basal medium with amorphous iron(III) oxide. Light microscopic observation revealed that the organism in these cultures was a spore-forming rod. The culture was then transferred $(5 \% \mathrm{v} / \mathrm{v})$ to fresh basal medium with AQDS, autoclaved at $121^{\circ} \mathrm{C}$ for 90 min to kill vegetative cells and incubated at $70{ }^{\circ} \mathrm{C}$. After $48 \mathrm{~h}$ incubation, this culture was serially diluted to extinction in agar shake tubes ( $1.5 \%$ Bacto Agar) in basal medium with AQDS and the procedure of isolation and subculturing of single colonies was repeated. After that, the culture was considered to be pure and was designated as strain $\mathrm{SR} 4^{\mathrm{T}}$.

\section{Colony and cell morphology}

In agar-shake cultures, the colonies appeared after $18-24 \mathrm{~h}$. The colonies were uniformly round, $0.5-1.0 \mathrm{~mm}$ in diameter and white. When grown in the basal medium with peptone and external electron acceptor [amorphous iron(III) oxide, AQDS, sulfite or thiosulfate], the vegetative cells of strain SR4 $4^{\mathrm{T}}$ were straight-to-curved rods, $0.4-0.6 \mu \mathrm{m}$ in diameter and $3.5-9.0 \mu \mathrm{m}$ in length (Fig. 1a, b). The cells occurred singly or in short chains, were peritrichous and exhibited a slight tumbling motility. The cells stained Gram-positive in both the exponential and stationary growth phases. Strain SR4 ${ }^{\mathrm{T}}$ formed round, refractile endospores in terminally swollen sporangia. Maximal sporulation was observed in liquid medium with AQDS: up to $10 \%$ of the cells sporulated during the late exponential phase. The cultures survived $90 \mathrm{~min}$ 


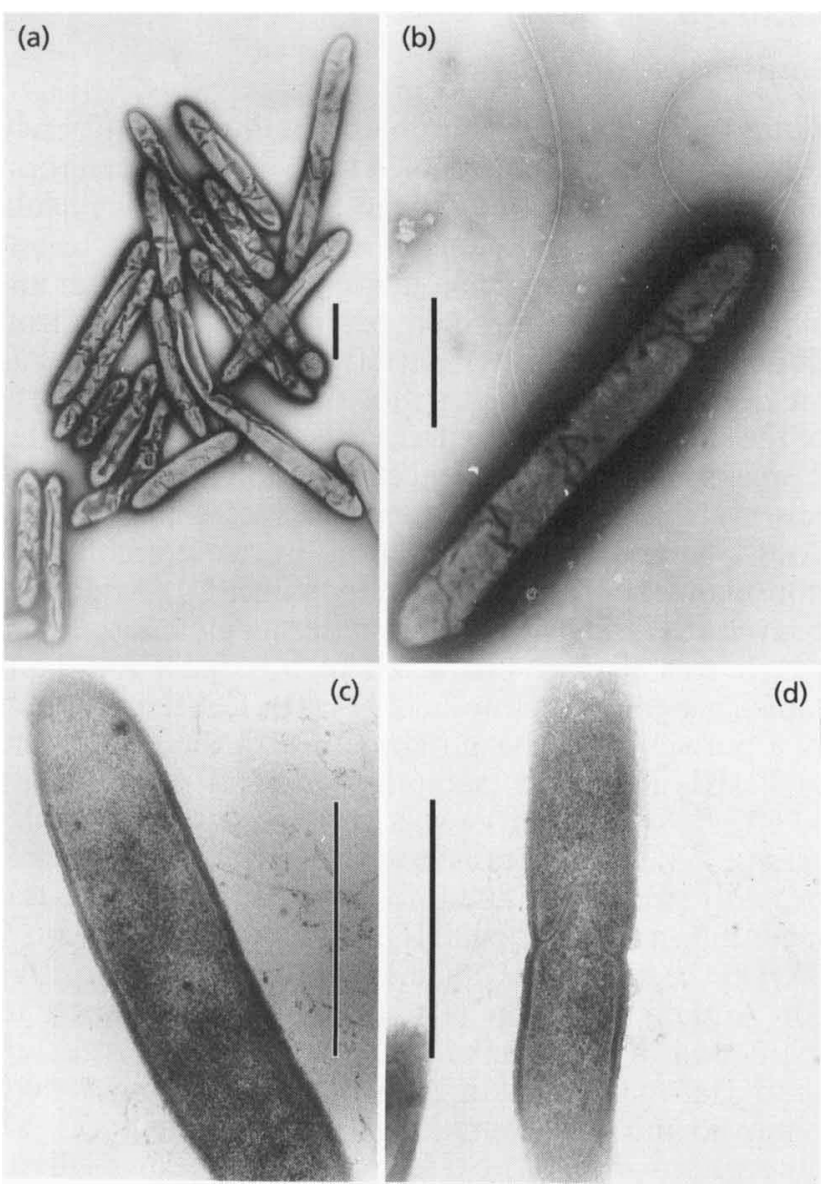

Fig. 1. Electron micrographs of strain SR4 ${ }^{\top}$ cells grown in basal medium with peptone as an electron donor and sulfite as an electron acceptor. (a) Negatively stained whole-cell specimen. (b) Cell with peritrichous flagella (negative staining). (c) Ultrathin section showing cell-wall layers. (d) Ultrathin section showing cell division. Bars, $1 \mu \mathrm{m}$.

exposure to $121^{\circ} \mathrm{C}$, thus confirming that the spores were heat resistant.

Ultrathin sectioning of strain SR4 ${ }^{\mathrm{T}}$ revealed a distinct peptidoglycan layer in the cell wall (Fig. 1c). The cells appeared to divide via a septation mechanism, with the formation of $\mathrm{V}$-shaped membrane invaginations (Fig. 1d).

\section{Growth and Fe(III) reduction}

Strain SR4 ${ }^{\mathrm{T}}$ grew anaerobically with peptone as the main organic carbon source (Fig. 2). Amorphous iron(III) oxide present in the medium stimulated the growth of strain SR4 $4^{\mathrm{T}}$. The number of cells increased with the concomitant accumulation of Fe(II). Without an external electron acceptor, the growth yield of SR $4^{\mathrm{T}}$ on peptone was reduced; addition of $\mathrm{Na}_{2} \mathrm{~S} .9 \mathrm{H}_{2} \mathrm{O}(0.5 \mathrm{~g}$ $\left.1^{-1}\right)$ to decrease the redox potential of the medium did not stimulate growth significantly. During the growth of strain $\mathrm{SR} 4^{\mathrm{T}}$ in medium with $\mathrm{Fe}(\mathrm{III})$, the production of molecular hydrogen was lower than during growth
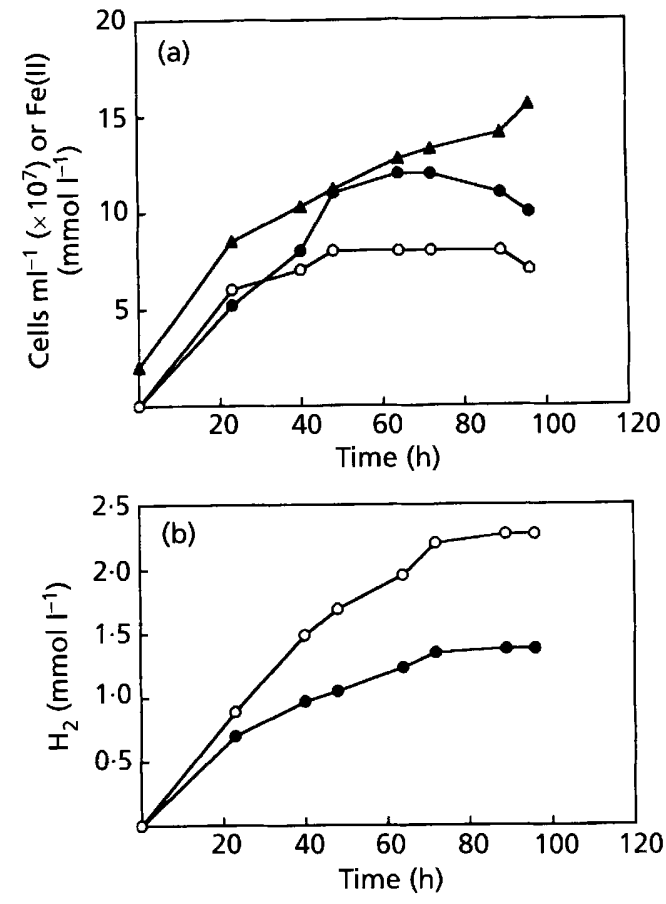

Fig. 2. Growth of and $\mathrm{Fe}(\mathrm{II})$ and $\mathrm{H}_{2}$ production by strain SR4 with peptone as a substrate with or without amorphous iron(III) oxide as an electron acceptor. (a) Growth in the presence (O) and absence (O) of $\mathrm{Fe}(\mathrm{III})$, and $\mathrm{Fe}(\mathrm{II})$ production ( $\boldsymbol{\Delta}$ ). (b) $\mathrm{H}_{2}$ production in the presence ( $)$ and absence $(\mathrm{O})$ of $\mathrm{Fe}(\mathrm{III})$.

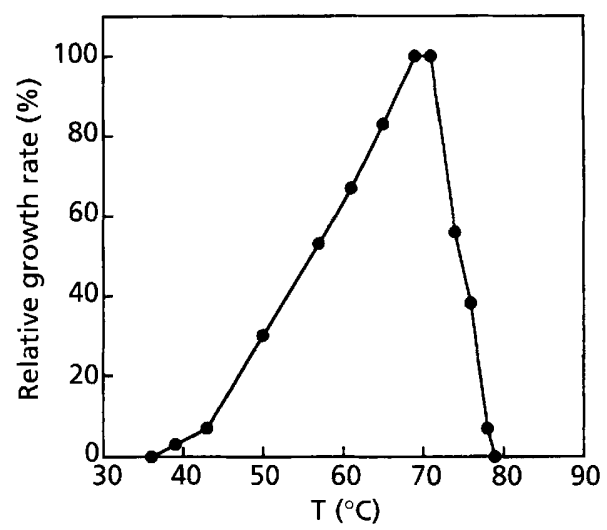

Fig. 3. Effect of temperature on the growth of strain SR4 ${ }^{\top}$. One hundred per cent was equivalent to a specific growth rate of $0 \cdot 24 \mathrm{~h}^{-1}$.

without $\mathrm{Fe}(\mathrm{III})$. Reduction of $\mathrm{Fe}(\mathrm{III})$ was not observed in non-inoculated medium with peptone $(1 \% \mathrm{w} / \mathrm{v})$, incubated at $70{ }^{\circ} \mathrm{C}$.

In the presence of amorphous iron(III) oxide, strain $\mathrm{SR}^{\mathrm{T}}$ grew on $\mathrm{H}_{2} / \mathrm{CO}_{2}(80: 20$ or $5: 95 \mathrm{v} / \mathrm{v})$ and utilized molecular hydrogen. The consumption of hydrogen did not exceed $5 \mathrm{mmol} \mathrm{H}_{2} \mathrm{l}^{-1}$ culture. For each mole of $\mathrm{H}_{2}$ consumed, $2 \cdot 15 \pm 0 \cdot 32 \mathrm{~mol}$ (mean $\pm \mathrm{SD}$ for five cultures) $\mathrm{Fe}(\mathrm{II})$ was produced. Cell number increased 


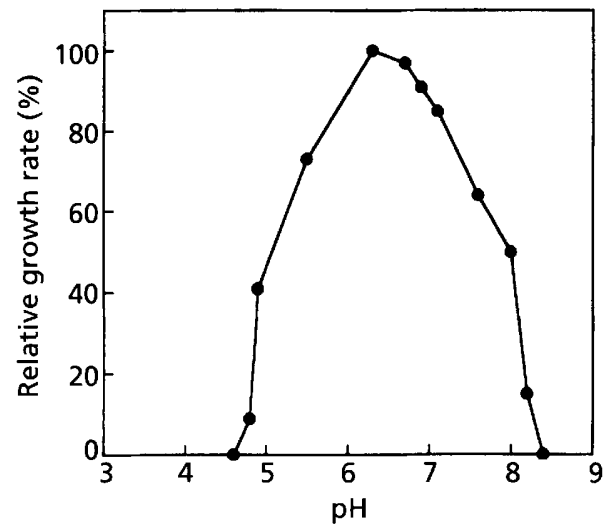

Fig. 4. Effect of $\mathrm{pH}$ on the growth of strain $\mathrm{SR}^{\top}$. One hundred per cent was equivalent to a specific growth rate of $0.24 \mathrm{~h}^{-1}$.

from $0 \cdot 9 \pm 0.3 \times 10^{6}$ cells $\mathrm{ml}^{-1}$ in inoculated cultures before growth to $2.5 \pm 0.5 \times 10^{7}$ cells $\mathrm{ml}^{-1}$ in outgrown cultures (mean \pm SD for five cultures). Without external electron acceptors, growth on $\mathrm{H}_{2} / \mathrm{CO}_{2}$ and consumption of $\mathrm{H}_{2}$ were not observed.

The products of amorphous iron(III) oxide reduction with peptone and molecular hydrogen as electron donors were magnetite and siderite.

\section{Physiological characteristics}

The temperature range for growth of strain SR $4^{\mathrm{T}}$ was $39-78^{\circ} \mathrm{C}$, with an optimum at $69-71{ }^{\circ} \mathrm{C}$ (Fig. 3). No growth was detected at $79^{\circ} \mathrm{C}$ or at temperatures of $36{ }^{\circ} \mathrm{C}$ or lower after 3 weeks incubation. The strain grew in a $\mathrm{pH}$ range from 4.8 to 8.2 , with an optimum at 6.3-6.5 (Fig. 4). No growth was detected at $\mathrm{pH} 4.6$ or 8.4. Growth of $\mathrm{SR}^{\mathrm{T}}$ was observed at $\mathrm{NaCl}$ concentrations ranging from 0 to $3 \cdot 5 \%(\mathrm{w} / \mathrm{v})$, with no growth evident at $4.0 \%(\mathrm{w} / \mathrm{v})$.

The substrates utilized by strain SR $4^{\mathrm{T}}$ in the presence, as well as in the absence, of Fe(III) as an electron acceptor included peptone $\left(10 \mathrm{~g}^{-1}\right)$, yeast extract $\left(10 \mathrm{~g}^{-1}\right)$, beef extract $\left(10 \mathrm{~g}^{-1}\right)$, casein $\left(10 \mathrm{~g} \mathrm{l}^{-1}\right)$, starch $\left(10 \mathrm{~g} \mathrm{l}^{-1}\right)$, glycerol $(20 \mathrm{mM})$, pyruvate $(20 \mathrm{mM})$, glucose $(25 \mathrm{mM})$, sucrose $(25 \mathrm{mM})$, fructose $(25 \mathrm{mM})$, maltose $(25 \mathrm{mM})$, xylose $(25 \mathrm{mM})$, cellobiose $(25 \mathrm{mM})$ and sorbitol $(25 \mathrm{mM})$. Strain SR4 ${ }^{\mathrm{T}}$ used $\mathrm{H}_{2} / \mathrm{CO}_{2}$ $(80: 20 \mathrm{v} / \mathrm{v})$ in the presence of $\mathrm{Fe}$ (III). Fe(III) was stimulatory for growth of strain SR4 ${ }^{\mathrm{T}}$ with all substrates utilized; however, Fe(III) was chemically reduced in sterile controls in the experiments with carbohydrates. Thus, the results of the test on stimulation of growth by $\mathrm{Fe}$ (III) on carbohydrates should be considered equivocal. Strain $\mathrm{SR} 4^{\mathrm{T}}$ did not use formate $(20 \mathrm{mM})$, acetate $(20 \mathrm{mM})$, lactate $(20 \mathrm{mM})$, methanol $(20 \mathrm{mM})$, ethanol (20 mM), propan-1-ol (20 mM), propan-2-ol $(20 \mathrm{mM})$, butan-1-ol $(20 \mathrm{mM})$, propionate $(20 \mathrm{mM}), n$-butyrate $(20 \mathrm{mM})$, succinate $(20 \mathrm{mM})$, malate $(20 \mathrm{mM})$, maleate $(20 \mathrm{mM})$, glycine $(20 \mathrm{mM})$, alanine $(20 \mathrm{mM})$, arginine $(20 \mathrm{mM})$, L-arabinose $(25 \mathrm{mM})$, olive oil $\left(10 \mathrm{ml} \mathrm{l}^{-1}\right)$, xylan

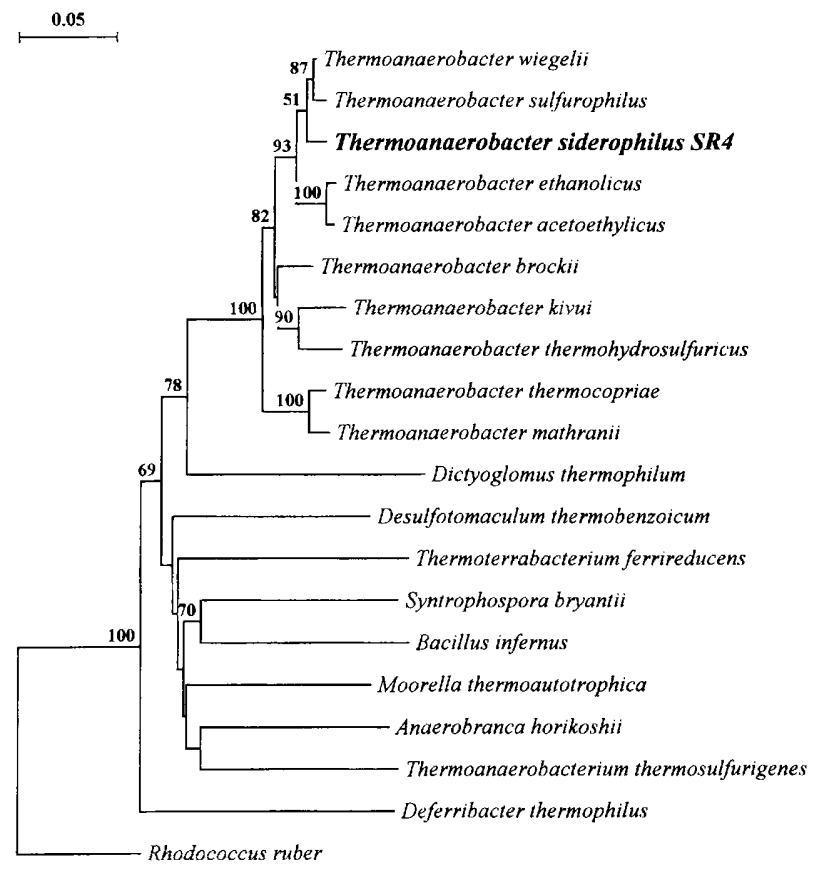

Fig. 5. Phylogenetic tree showing the position of Thermoanaerobacter siderophilus $\mathrm{SR}^{\top}$. The scale bar represents the expected number of changes per sequence position.

$\left(10 \mathrm{~g}^{-1}\right)$, carboxymethylcellulose $\left(10 \mathrm{~g}^{-1}\right)$ or filter paper $\left(10 \mathrm{~g}^{-1}\right)$, with or without $\mathrm{Fe}$ (III) as an electron acceptor. The fermentation products from glucose were ethanol, lactate, $\mathrm{H}_{2}$ and $\mathrm{CO}_{2}$.

Strain $\mathrm{SR}^{\mathrm{T}}$ reduced amorphous iron(III) oxide $(90 \mathrm{mM})$, AQDS $(20 \mathrm{mM})$, sulfite $(5 \mathrm{mM})$, thiosulfate $(20 \mathrm{mM})$, elemental sulfur $(150 \mathrm{mM})$ and $\mathrm{MnO}_{2}(20$ $\mathrm{mM}$ ). Sulfite, thiosulfate and elemental sulfur were reduced to hydrogen sulfide. Reduction of $\mathrm{MnO}_{2}$ resulted in the formation of a whitish precipitate composed of the $\mathrm{Mn}(\mathrm{II})$ state. Strain SR4 ${ }^{\mathrm{T}}$ did not reduce nitrate $(20 \mathrm{mM})$ or sulfate $(20 \mathrm{mM})$ and was not capable of growth with $\mathrm{O}_{2}(20 \% \mathrm{v} / \mathrm{v}$ in the gas phase).

Chloramphenicol, neomycin, polymyxin B and kanamycin completely inhibited growth at concentrations of $100 \mu \mathrm{g} \mathrm{ml}^{-1}$ medium. Penicillin, ampicillin, streptomycin and novobiocin at $100 \mu \mathrm{g} \mathrm{ml}^{-1}$ did not inhibit growth.

\section{DNA characteristics and phylogenetic analysis}

The $\mathrm{G}+\mathrm{C}$ content of the genomic DNA of strain SR $4^{\mathrm{T}}$ was $32 \mathrm{~mol} \%\left(T_{\mathrm{m}}\right)$. The molecular mass of genomic DNA of strain SR4 ${ }^{\mathrm{T}}$ was $3.14 \times 10^{9} \mathrm{Da}$.

We determined an almost complete $16 \mathrm{~S}$ rDNA sequence for strain SR4 ${ }^{\mathrm{T}}$, corresponding to positions 11-1506 of Escherichia coli numbering. Phylogenetic analysis of $16 \mathrm{~S}$ rDNA sequences placed strain SR $4^{\mathrm{T}}$ in the cluster comprising members of the genus Thermoanaerobacter, with a mean sequence identity of $95.9 \%$ (Fig. 5). The closest relatives of strain $\mathrm{SR} 4^{\mathrm{T}}$ were 
Table 1. Specific elements of the secondary structure of 16S rRNA in different Thermoanaerobacter species

Helix types present in each region of the 16S rRNA are shown for each taxon.

\begin{tabular}{|c|c|c|c|c|}
\hline \multirow[t]{2}{*}{ Species } & \multicolumn{4}{|c|}{$\begin{array}{c}\text { Region of } 16 \mathrm{~S} \\
\text { rRNA sequence } \\
\text { ( } E \text {. coli } \\
\text { numbering })\end{array}$} \\
\hline & 80 & 1040 & 1140 & 1440 \\
\hline T. siderophilus strain SR4 ${ }^{\mathrm{T}}$ & 1 & 1 & 2 & 2 \\
\hline T. wiegelii & 1 & 2 & 2 & 2 \\
\hline T. sulfurophilus & 1 & 2 & 2 & 2 \\
\hline T. acetoethylicus & 1 & 3 & 1 & 1 \\
\hline T. ethanolicus & 1 & 3 & 1 & 1 \\
\hline T. kivui & 2 & 2 & 2 & 1 \\
\hline T. thermohydrosulfuricus & 2 & 1 & 1 & 1 \\
\hline T. mathranii & 3 & 2 & 2 & 2 \\
\hline T. brockii & 3 & 2 & 2 & 2 \\
\hline T. thermocopriae & 3 & 2 & 2 & 2 \\
\hline
\end{tabular}

Thermoanaerobacter wiegelii and Thermoanaerobacter sulfurophilus (levels of identity 98.1 and $97.9 \%$, respectively). However, bootstrap values for the branching point of strain SR4 $4^{T}$ (less than $50 \%$ ) indicate that its position is not yet conclusively resolved.

The affiliation of strain SR $4^{\mathrm{T}}$ to the genus Thermoanaerobacter is also supported by additional secondary structure analysis. Comparison of the 16S rRNA sequences of Thermoanaerobacter species with smallsubunit rRNA of prokaryotes revealed the presence of unique long versions of certain helices around positions $80,1040,1140$ and 1440 (E. coli numbering) (Rainey et al., 1993). The number and type of long versions of these helices vary in different Thermoanaerobacter species (Table 1). Strain SR4 ${ }^{\mathrm{T}}$ differed from all validly described Thermoanaerobacter species by the combination of specific versions of these helices.

Considering the high levels of identity (more than $97 \%$ ) between the $16 \mathrm{~S}$ rRNA sequences of strain SR4 ${ }^{\mathrm{T}}$ and Thermoanaerobacter wiegelii and Thermoanaerobacter sulfurophilus, quantitative DNA-DNA hybridization experiments were performed. The levels of DNA reassociation were: between strain $\mathrm{SR} 4^{\mathrm{T}}$ and Thermoanaerobacter wiegelii, $50 \%$, and between strain SR $4^{\mathrm{T}}$ and Thermoanaerobacter sulfurophilus, $48 \%$. These data confirm that strain SR4 ${ }^{\mathrm{T}}$ is a new species of the genus Thermoanaerobacter.

\section{DISCUSSION}

Iron-containing compounds are abundant in some terrestrial, geothermally heated sediments in Kamchatka (Karpov, 1976). The fact that strain SR4 ${ }^{\mathrm{T}}$ was isolated from a sample that was collected within 5 months of the formation of hydrothermal vents in the area of the eruption of Karymsky volcano indicates early colonization of high-temperature environments by micro-organisms capable of Fe(III) reduction.

Strain SR $4^{\mathrm{T}}$ is a facultative Fe(III) reducer, capable of oxidizing organic substrates in the presence and absence of $\mathrm{Fe}$ (III). The mechanism of microbial Fe(III) reduction with complex organic substances, such as peptone, is unknown and may include fermentative as well as respiratory types of dissimilatory $\mathrm{Fe}(\mathrm{III})$ reduction. Greater cell numbers were obtained in media containing Fe(III), suggesting that Fe(III) reduction may play a role in energy conservation. Strain $\mathrm{SR} 4^{\mathrm{T}}$ is also capable of molecular-hydrogen oxidation in the presence of $\mathrm{Fe}(\mathrm{III})$. Although the net consumption of $\mathrm{H}_{2}$ was relatively low, it was enough for sustainable growth and formation of a magnetic precipitate. The finding that strain SR $4^{\mathrm{T}}$ can reduce $\mathrm{Mn}(\mathrm{IV})$ extends the known upper temperature limit for biological manganese reduction to $76^{\circ} \mathrm{C}$.

The anaerobic, thermophilic, endospore-forming bacteria that are unable to reduce sulfate are currently placed in the genera Clostridium, Thermoanaerobacter, Thermoanaerobacterium, Caloramator and Moorella (Collins et al., 1994; Lee et al., 1993; Wiegel, 1986). The results of $16 \mathrm{~S}$ rDNA sequence analysis placed strain SR4 $4^{\mathrm{T}}$ in the cluster composed of Thermoanaerobacter species.

The capacity for dissimilatory $\mathrm{Fe}(\mathrm{III})$ reduction has not been tested among the members of the genus Thermoanaerobacter. The involvement of Thermoanaerobacter species in Fe(III) reduction in the deep subsurface was suggested by Liu et al. (1997) on the basis of molecular analysis; however, pure cultures of the micro-organisms were not obtained. We tested two species of Thermoanaerobacter most closely related to strain SR4 $4^{\mathrm{T}}$ on the basis of $16 \mathrm{~S}$ rDNA identity, and found both Thermoanaerobacter wiegelii (Cook et al., 1996) and Thermoanaerobacter sulfurophilus (BonchOsmolovskaya et al., 1997) to be capable of dissimilatory $\mathrm{Fe}(\mathrm{III})$ reduction during growth with peptone as the electron donor and amorphous iron(III) oxide as the electron acceptor. However, the rate of $\mathrm{Fe}$ (III) reduction was considerably lower than that observed with strain SR4 ${ }^{\mathrm{T}}$. Thermoanaerobacter wiegelii and Thermoanaerobacter sulfurophilus did not reduce amorphous iron(III) oxide significantly with glycerol or lactate, respectively, as electron donors. These findings indicate that the capacity for dissimilatory $\mathrm{Fe}(\mathrm{III})$ reduction with complex organic substrates as electron donors may be widespread among the members of the genus Thermoanaerobacter. The stimulation of growth of strain SR $4^{\mathrm{T}}$ by $\mathrm{Fe}$ (III) resembles the positive effect of thiosulfate or elemental sulfur on the growth of some Thermoanaerobacter species (Fardeau et al., 1994; Faudon et al., 1995; BonchOsmolovskaya et al., 1997) and probably has a similar mechanism. 
Table 2. Characteristics that differentiate $T$. siderophilus from $T$. wiegelii and T. sulfurophilus

\begin{tabular}{|lccc|}
\hline Characteristic & T. siderophilus & T. wiegelii & T. sulfurophilus \\
\hline Reduction of elemental sulfur & + & - & + \\
Temperature optimum $\left({ }^{\circ} \mathrm{C}\right)$ & $69-71$ & $65-68$ & $55-60$ \\
pH optimum & $6 \cdot 3-6 \cdot 5$ & $6 \cdot 8$ & $6 \cdot 8-7 \cdot 2$ \\
G + C content of DNA $(\mathrm{mol} \%)$ & 32 & 35 & 30 \\
Mass of genome DNA $(\mathrm{Da})^{*}$ & $3 \cdot 14 \times 10^{9}$ & $3 \cdot 77 \times 10^{9}$ & $3.94 \times 10^{9}$ \\
\hline
\end{tabular}

* Masses of genomes of $T$. wiegelii and $T$. sulfurophilus were determined in this study.

Strain SR4 ${ }^{\mathrm{T}}$ differs from Thermoanaerobacter wiegelii and Thermoanaerobacter sulfurophilus in the temperature and $\mathrm{pH}$ optima, capacity for reduction of elemental sulfur, $\mathrm{G}+\mathrm{C}$ content of DNA and size of genome (Table 2). The fact that strain SR4 ${ }^{\mathrm{T}}$ does not belong to any of the described Thermoanaerobacter species is also supported by the presence of a specific combination of long versions of helices in four regions of $16 \mathrm{~S}$ rRNA. On the basis of physiological properties and phylogenetic analysis, we propose that strain SR $4^{\mathrm{T}}$ should be assigned to a new species of the genus Thermoanaerobacter.

\section{Description of Thermoanaerobacter siderophilus sp. nov.}

Thermoanaerobacter siderophilus (si.de.ro'phil.us. Gr. n. sideros iron; Gr. adj. philos loving; M.L. adj. siderophilus iron-loving).

Cells are straight-to-curved rods, $0.4-0.6 \mu \mathrm{m}$ in diameter and 3.5-9.0 $\mu \mathrm{m}$ in length, forming round, refractile, heat-resistant endospores in terminally swollen sporangia. Cells occur singly and exhibit slight tumbling motility due to peritrichous flagellation. Anaerobic. The temperature range for growth is $39-78^{\circ} \mathrm{C}$, with an optimum at $69-71^{\circ} \mathrm{C}$. Neutrophilic: $\mathrm{pH}$ range for growth is from 4.8 to 8.2 , with an optimum at $6 \cdot 3-6 \cdot 5$. Growth occurs in an $\mathrm{NaCl}$ concentration range of $0-3 \cdot 5 \%(\mathrm{w} / \mathrm{v})$. The substrates utilized in the presence, as well in the absence, of $\mathrm{Fe}(\mathrm{III})$ as an electron acceptor include peptone, yeast extract, beef extract, starch, glycerol, pyruvate, glucose, sucrose, fructose, maltose, xylose, cellobiose and sorbitol. Utilizes molecular hydrogen in the presence of $\mathrm{Fe}(\mathrm{III})$. No growth occurs with formate, acetate, lactate, methanol, ethanol, propan-1-ol, propan-2-ol, butan-1-ol, propionate, $n$-butyrate, succinate, malate, maleate, glycine, alanine, arginine, L-arabinose, olive oil, xylan or cellulose, either with or without Fe(III) as an electron acceptor. The fermentation products from glucose are ethanol, lactate, $\mathrm{H}_{2}$ and $\mathrm{CO}_{2}$. Reduces amorphous iron(III) oxide, AQDS, sulfite, thiosulfate, elemental sulfur and $\mathrm{MnO}_{2}$. The products of amorphous iron(III) oxide reduction are magnetite and siderite. Sulfite, thiosulfate and elemental sulfur are reduced to hydrogen sulfide. Does not reduce nitrate or sulfate and is incapable of growth with $\mathrm{O}_{2}$. Growth is inhibited by chloramphenicol, neomycin, polymyxin $\mathrm{B}$ and kanamycin but not by penicillin, ampicillin, streptomycin or novobiocin. $\mathrm{G}+\mathrm{C}$ content of DNA of the type strain is $32 \mathrm{~mol} \%$. The habitat is hydrothermal vents in the area of Karymsky volcano on the Kamchatka peninsula, Russia. The type strain is $\mathrm{SR} 4^{\mathrm{T}}$, which has been deposited with the Deutsche Sammlung von Mikroorganismen und Zellkulturen under the accession number DSM $12299^{\mathrm{T}}$.

\section{ACKNOWLEDGEMENTS}

This work was supported in part by Genencor International and by grants 98-04-49079 and 96-04-50820 from the Russian Foundation for Basic Research. We thank G. A. Karpov for providing environmental samples and $\mathrm{A}$. Lebedinsky for valuable discussion of the manuscript.

\section{REFERENCES}

Balashova, V. V. \& Zavarzin, G. A. (1980). Anaerobic reduction of ferric iron by hydrogen bacteria. Microbiology (English translation of Mikrobiologiya) 48, 635-639.

Bonch-Osmolovskaya, E. A., Sokolova, T. G., Kostrikina, N. A. \& Zavarzin, G. A. (1990). Desulfurella acetivorans gen. nov. and sp. nov. - a new thermophilic sulfur-reducing eubacterium. Arch Microbiol 153, 151-155.

Bonch-Osmolovskaya, E. A., Miroshnichenko, M. L., Chernyh, N. A., Kostrikina, N. A., Pikuta, E. V. \& Rainey, F. A. (1997). Reduction of elemental sulfur by moderately thermophilic organotrophic bacteria and the description of Thermoanaerobacter sulfurophilus sp. nov. Microbiology (English translation of Mikrobiologiya) 66, 483-489.

Boone, D. R., Liu, Y., Zhao, Z.-J., Balkwill, D. L., Drake, G. R., Stevens, T. O. \& Aldrich, H. C. (1995). Bacillus infernus sp. nov., an $\mathrm{Fe}(\mathrm{III})$ - and $\mathrm{Mn}(\mathrm{IV})$-reducing anaerobe from the deep terrestrial subsurface. Int J Syst Bacteriol 45, 441-448.

Bridge, T. A. M. \& Johnson, D. B. (1998). Reduction of soluble iron and reductive dissolution of ferric iron-containing minerals by moderately thermophilic iron-oxidizing bacteria. Appl Environ Microbiol 64, 2181-2186.

Brock, T. D. \& Gustafson, J. (1976). Ferric iron reduction by sulfur- and iron-oxidizing bacteria. Appl Environ Microbiol 32, 567-571.

Collins, M. D., Lawson, P. A., Willems, A., Cordoba, J. J., Fernandez-Garayzabal, J., Garcia, P., Cai, J., Hippe, H. \& Farrow, J. A. E. (1994). The phylogeny of the genus Clostridium: proposal 
of five new genera and eleven new species combinations. Int $J$ Syst Bacteriol 44, 812-826.

Cook, G. M., Rainey, F. A., Patel, B. K. C. \& Morgan, H. W. (1996). Characterization of a new obligately anaerobic thermophile, Thermoanaerobacter wiegelii sp. nov. Int J Syst Bacteriol 46, 123-127.

Corpet, F. (1988). Multiple sequence alignment with hierarchical clustering. Nucleic Acids Res 16, 10881-10890.

Fardeau, M. L., Cayol, J. L., Magot, M. \& Ollivier, B. (1994). Hydrogen oxidation abilities in the presence of thiosulfate as electron acceptor within the genus Thermoanaerobacter. Curr Microbiol 29, 269-272.

Faudon, C., Fardeau, M. L., Heim, J., Patel, B., Magot, M. \& Ollivier, B. (1995). Peptide and amino acid oxidation in the presence of thiosulfate by members of the genus Thermoanaerobacter. Curr Microbiol 31, 152-157.

Gillis, M., De Ley, J. \& De Cleene, M. (1970). The determination of molecular weight of bacterial genome DNA from renaturation rates. Eur J Biochem 12, 143-153.

Greene, A. C., Patel, B. K. C. \& Sheehy, A. J. (1997). Deferribacter thermophilus gen. nov., sp. nov., a novel thermophilic manganese- and iron-reducing bacterium isolated from a petroleum reservoir. Int J Syst Bacteriol 47, 505-509.

Jukes, T. H. \& Cantor, C. R. (1969). Evolution of protein molecules. In Mammalian Protein Metabolism, pp. 21-132. Edited by H. N. Munro. New York: Academic Press.

Karpov, G. A. (1976). Experimental Investigations of the Mineral Formation in Geothermal Wells. Moscow: Nauka (in Russian).

Krivenko, V. V., Vadachkoriya, R. M., Chernykh, N. A., Mityushina, L. L. \& Krassilnikova, E. N. (1990). Clostridium uzonii sp. nov., an anaerobic thermophilic glycolytic bacterium from the hot springs of Kamchatka. Microbiology (English translation of Mikrobiologiya) 59, 741-749.

Lane, D. J. (1991). 16S/23S rRNA sequencing. In Nucleic Acid Techniques in Bacterial Systematics, pp. 115-147. Edited by E. Stackebrandt \& M. Goodfellow. New York: Wiley.

Lee, Y.-E., Jain, M. K., Lee, C., Lowe, S. E. \& Zeikus, J. G. (1993). Taxonomic distinction of saccharolytic anaerobes: description of Thermoanaerobacterium xylanolyticum gen. nov., sp. nov., and Thermoanaerobacterium saccharolyticum gen. nov., sp. nov.; reclassification of Thermoanaerobium brockii, Clostridium thermosulfurogenes, and Clostridium thermohydrosulfuricum E100-69 as Thermoanaerobacter brockii comb. nov., Thermoanaerobacterium thermosulfurogenes comb. nov., and Thermoanaerobacter thermohydrosulfuricus comb. nov., respectively; and transfer of Clostridium thermohydrosulfuricum $39 \mathrm{E}$ to Thermoanaerobacter ethanolicus. Int $J$ Syst Bacteriol 43, 41-51.

Liu, S. V., Zhou, J., Zhang, C., Cole, D. R., Gajdarziska-Josifovska, M. \& Phelps, T. J. (1997). Thermophilic Fe(III)-reducing bacteria from the deep subsurface: the evolutionary implications. Science 277, 1106-1109.
Lovley, D. R. (1991). Dissimilatory Fe(III) and $\mathrm{Mn}(\mathrm{IV})$ reduction. Microbiol Rev 55, 259-287.

Lovley, D. R. (1995). Microbial reduction of iron, manganese, and other metals. Adv Agron 54, 175-231.

Lovley, D. R. \& Phillips, E. J. P. (1988). Novel mode of microbial energy metabolism: organic carbon oxidation coupled to dissimilatory reduction of iron and manganese. Appl Environ Microbiol 54, 1472-1480.

Marmur, J. (1961). A procedure for the isolation of deoxyribonucleic acid from microorganisms. J Mol Biol 3, 208-218.

Marmur, J. \& Doty, P. (1962). Determination of the base composition of deoxyribonucleic acid from its thermal denaturation temperature. $J$ Mol Biol 4, 109-118.

Nealson, K. H. \& Saffarini, D. (1994). Iron and manganese in anaerobic respiration: environmental significance, physiology, and regulation. Annu Rev Microbiol 48, 311-343.

Norris, J. R. \& Swain, H. (1971). Staining bacteria. Methods Microbiol 5A, 105-135.

Rainey, F. A., Ward, N. L., Morgan, H. W., Toalster, R. \& Stackebrandt, E. (1993). Phylogenetic analysis of anaerobic thermophilic bacteria: aid for their reclassification. $J$ Bacteriol 175, 4772-4779.

Saitou, N. \& Nei, M. (1987). The neighbor-joining method: a new method for reconstructing phylogenetic trees. Mol Biol Evol 4, 406-425.

Slobodkin, A. I. \& Bonch-Osmolovskaya, E. A. (1994). Growth and formation of metabolic products by extremely thermophilic archaea of the genus Desulfurococcus in the presence and absence of elemental sulfur. Microbiology (English translation of Mikrobiologiya) 63, 552-554.

Slobodkin, A. I. \& Wiegel, J. (1997). Fe(III) as an electron acceptor for $\mathrm{H}_{2}$ oxidation in thermophilic anaerobic enrichment cultures from geothermal areas. Extremophiles 1, 106-109.

Slobodkin, A. I., Eroshchev-Shak, V. A., Kostrikina, N. A., Lavrushin, V. Y., Dainyak, L. G. \& Zavarzin, G. A. (1995). Magnetite formation by thermophilic anaerobic microorganisms. Dokl Akad Nauk 345, 694-697 (in Russian).

Slobodkin, A., Reysenbach, A.-L., Strutz, N., Dreier, M. \& Wiegel, J. (1997). Thermoterrabacterium ferrireducens gen. nov., sp. nov., a thermophilic anaerobic dissimilatory Fe(III)-reducing bacterium from a continental hot spring. Int J Syst Bacteriol 47, 541-547.

Van de Peer, Y. \& De Wachter, R. (1994). TREECON for Windows: a software package for the construction and drawing of evolutionary trees for the Microsoft Windows environment. Comput Appl Biosci 10, 569-570.

Wiegel, J. K. W. (1986). Genus Thermoanaerobacter. In Bergey's Manual of Systematic Bacteriology, vol. 2, pp. 1379-1383. Edited by P. H. A. Sneath, N. S. Mair, M. E. Sharpe \& J. G. Holt. Baltimore: Williams \& Wilkins.

Wolin, E. A., Wolin, M. J. \& Wolfe, R. S. (1963). Formation of methane by bacterial extracts. $J$ Biol Chem 238, 2882-2886. 